\title{
Radiation-enhancement of MDA-MB-23I breast cancer cell invasion prevented by a cyclooxygenase-2 inhibitor
}

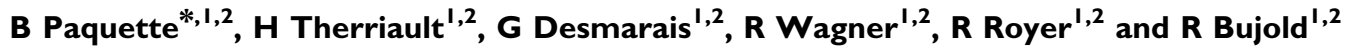 \\ 'Department of Nuclear Medicine and Radiobiology, Faculty of Medicine and Health Sciences, Université de Sherbrooke; ${ }^{2}$ Center for Research in \\ Radiotherapy, 300I, I 2e Avenue Nord, Sherbrooke, Quebec, Canada JIH 5N4
}

BACKGROUND: Recent evidences support that radiation can promote the invasion of cancer cells. As interactions between cancer cells and surrounding stromal cells can have an important role in tumour progression, we determined whether an irradiation to fibroblasts can enhance the invasiveness of breast cancer cells. The role of cyclooxygenase-2 (COX-2), an inflammatory enzyme frequently induced by radiotherapy, was investigated.

METHODS: Irradiated 3T3 fibroblasts were plated in the lower compartment of invasion chambers and used as chemoattractant for non-irradiated human breast cancer cell MDA-MB-23I, which are oestrogen receptor negative $(E R(-))$ and the oestrogen receptor positive $(E R(+))$ MCF-7 cells. Stimulation of COX-2 expression in irradiated 3T3 cells was measured by a semi-quantitative qPCR and western blot. Capacity of the major product of COX-2, the prostaglandin E2 ( $\left.\mathrm{PGE}_{2}\right)$, to stimulate the production of the matrix metalloproteinase-2 (MMP-2) and cancer cell invasion were assessed with a zymography gel and invasion chambers.

RESULTS: Irradiation (5 Gy) of 3T3 fibroblasts increased COX-2 expression and enhanced by 5.8-fold the invasiveness of non-irradiated MDA-MB-23I cells, while their migration was not modified. Addition of the COX-2 inhibitor NS-398 completely prevented radiation-enhancement of cancer cell invasion. Further supporting the potential role of COX-2, addition of $\mathrm{PGE}_{2}$ has increased cancer cell invasion and release of MMP-2 from the MDA-MB-23I cells. This effect of radiation was dependant on the expression of membrane type I (MTI)-MMP, which is required to activate the MMP-2, but was not associated with the ER status. Although irradiated fibroblasts stimulated the invasiveness of MDA-MB-23। ER $(-)$ cells, no enhancement was measured with the ER(+) cell line MCF-7.

CONCLUSIONS: Radiation-enhancement of breast cancer cell invasion induced by irradiated 3T3 fibroblasts is not dependant on the ER status, but rather the expression of MTI-MMP. This adverse effect of radiation can be prevented by a specific COX-2 inhibitor. British Journal of Cancer (20II) I 05, 534-54I. doi:I0.1038/bjc.20II.260 www.bjcancer.com

Published online 26 July 2011

(C) 201 I Cancer Research UK

Keywords: breast cancer; cyclooxygenase-2; radiation therapy; invasion

Malignant microfoci scattered throughout the breast tissue are present in $39-63 \%$ of breast cancer patients who are clinically and mammographically suspected of having unifocal breast cancer (Lagios et al, 1981; Holland et al, 1985). To eliminate residual cancer cells scattered in the breast, the radiation dose distribution used in radiotherapy is designed to irradiate the whole breast and frequently the axillaries and supraclavicular lymphatic nodes as well. Consequently, a large volume of healthy tissue is exposed to radiation. Moreover, a fraction of the cancer cells scatter in the breast could not be eliminated since the radiation treatment aims at optimising long-term results with minimal adverse effects to normal tissues, and not to eliminate all cancer cells.

Induction of an acute erythema and fibrosis by radiation are common adverse effects observed in patients under-going radiotherapy treatment (Nystrom et al, 2004; Lind, 2006). Some studies

*Correspondence: Dr B Paquette;

E-mail: Benoit.Paquette@USherbrooke.ca

Revised 10 June 2011; accepted 16 June 201 I; published online 26 July 2011 suggest that up to $95 \%$ of patients treated with postoperative external radiotherapy for breast cancer will experience some kind of skin reaction (De Conno et al, 1991). Early inflammatory response can occur during the radiotherapy treatment, while late side-effects appear months or even years after treatment and can even be irreversible (Nystrom et al, 2004).

Cyclooxygenase-2 (COX-2) is a key enzyme in the inflammatory response, which mainly produces the prostaglandin E2 $\left(\mathrm{PGE}_{2}\right)$ (Liang et al, 2003). Overexpression of COX-2 and $\mathrm{PGE}_{2}$ were associated with unfavourable prognoses in breast cancer patients (Leppa et al, 2004; Schmitz et al, 2006). This prostaglandin can be involved in cancer cell invasion by stimulating the expression of matrix metalloproteinase 2 (MMP-2) (Yao et al, 2004; Larkins et al, 2006). This latter protease is required to cross the basement membrane, which acts as a barrier to cancer cell invasion (Rooprai and McCormick, 1997; Fillmore et al, 2001).

As radiation can stimulate the activity of COX-2 (Liang et al, 2003), the potential role of radiation to increase the invasiveness of cancer cell was investigated. An enhancement of cancer cell invasion after their irradiation has been reported for pancreatic 
cancer cells (Qian et al, 2002; Ohuchida et al, 2004), glioma cells (Wild-Bode et al, 2001; Park et al, 2006), melanoma cells (Rofstad et al, 2004; Kaliski et al, 2005), rectal carcinoma cells (Speake et al, 2005) and colon carcinoma cells (Wang et al, 2000). These studies were designed to evaluate the invasiveness of irradiated cancer cells, which would survival after radiation treatment.

The objective of this study was to determine the potential role of irradiated fibroblasts in the invasiveness of the human breast cancer cell MDA-MB-231 and MCF-7, which are oestrogen receptor negative $(\operatorname{ER}(-))$ and oestrogen receptor positive $(\operatorname{ER}(+))$, respectively. Role of the membrane type 1 (MT1)-MMP in radiation-enhancement of breast cancer cell invasion was also assessed. As our hypothesis is based on a participation of COX-2, the ability of a COX-2 inhibitor to prevent radiation-enhancement of breast cancer cells invasion was determined.

\section{MATERIALS AND METHODS}

\section{Chemicals and reagents}

Unless otherwise indicated, all reagents were purchased from Sigma-Aldrich (Oakville, Ontario, Canada).

\section{Mammary cell culture}

The human breast cancer cell lines MDA-MB-231 and MCF-7 as well as the $3 \mathrm{~T} 3$ fibroblasts were obtained from the American Type Culture Collection (Manassas, VA, USA). They were maintained in minimum essential medium (MEM) supplemented with sodium pyruvate $(1 \mathrm{~mm}), 10 \% \mathrm{FBS}$, penicillin $\left(50\right.$ units $\left.\mathrm{ml}^{-1}\right)$ and streptomycin $\left(50 \mu \mathrm{g} \mathrm{ml}^{-1}\right)$.

\section{Cancer cell invasion and migration assay}

For the invasion assay, the $3 \mathrm{~T} 3$ fibroblasts $\left(2.5 \times 10^{4}\right)$ plated in 24-well plates were incubated for $20 \mathrm{~h}$ in MEM medium supplemented with $10 \%$ FBS. The culture medium was then removed, cells rinsed twice with PBS and MEM medium supplemented with $0.1 \%$ BSA was added. Cells were irradiated using a ${ }^{60}$ Co source (Gammacell 220, Nordion, Canada) at a dose of $5 \mathrm{~Gy}$. Non-irradiated cells were used as control. These different conditioned media were used as chemoattractant in the lower compartment of invasion chambers (Becton Dickinson Biosciences, Bedford, MA, USA). Non-irradiated MDA-MB-231 and MCF-7 cells harvested with cell dissociation solution were added $\left(4 \times 10^{4}\right)$ to the upper compartment of the invasion chambers right after irradiation of the 3T3 cells in the lower compartment or $24 \mathrm{~h}$ later. For the invasion assays regarding the role of the MT1-MMP, the MT1-MMP antibody (Abcam, Cambridge, MA, USA) was added to a final concentration of $10 \mu \mathrm{g} \mathrm{ml}^{-1}$ to the MDA-MB-231 cells $30 \mathrm{~min}$ before the invasion assay at $37^{\circ} \mathrm{C}$. To assess the role of COX-2, the invasion assay was repeated with $3 \mathrm{~T} 3$ fibroblasts incubated with $10 \mu \mathrm{M}$ NS-398 (Cayman Chemical, Ann Arbor, MI, USA) $1 \mathrm{~h}$ before their irradiation. Breast cancer cells that had crossed the Matrigel and the porous membrane $24 \mathrm{~h}$ later were fixed, stained and counted under the microscope.

Regarding the migration assay, the same experimental conditions were used except that $1 \times 10^{4}$ MDA-MB-231 cells were plated in the upper compartment of the migration chamber, which were not coated with a layer of Matrigel (Becton Dickinson Biosciences). Each experimental condition was performed in duplicate and repeated four times.

\section{MMP-2 analysis by zymography gel}

The MDA-MB-231 cells $\left(1.25 \times 10^{5}\right.$ in 12 -well plate) were incubated on a layer of Matrigel (diluted 1/5) in MEM supplemented with $10 \%$ FBS for $18 \mathrm{~h}$. The culture media was then removed, cells washed twice with $\mathrm{PBS}$ and $\mathrm{PGE}_{2}$ was added at the concentration indicated. Conditioned media containing the MMP-2 was analysed $24 \mathrm{~h}$ later by zymography gel as previously done in our laboratory (Paquette et al, 2007).

\section{Extraction of $\mathrm{PGE}_{2}$}

3T3 fibroblasts $\left(2.5 \times 10^{5}\right)$ plated in six-well plates were incubated for $24 \mathrm{~h}$ in MEM medium supplemented with $10 \%$ FBS. The culture medium was then removed, cells rinsed twice with PBS and MEM medium supplemented with $0.1 \%$ BSA was added. When indicated, 3T3 cells were incubated with $10 \mu \mathrm{M}$ NS-398 $1 \mathrm{~h}$ before irradiation (5 Gy). The internal standard $\mathrm{PGE}_{2} \mathrm{~d}_{4}$ (Cayman) at a concentration of $10 \mathrm{ng} \mathrm{ml}^{-1}$ was added to conditioned media of 3T3 cells isolated $24 \mathrm{~h}$ after the irradiation. Butylhydroxytoluene (10\%) was added to prevent peroxidation by free radicals, and the samples were stored at $-20^{\circ} \mathrm{C}$. Prostaglandins extraction was made according to Yang et al (2002). Briefly, $1 \mathrm{ml}$ of acetone was added to cell supernatant, mixed and centrifuged at $1800 \mathrm{~g}$ for $10 \mathrm{~min}$ at $4{ }^{\circ} \mathrm{C}$. Supernatant was then transferred to another tube with $1 \mathrm{ml}$ hexane: ethyl acetate $(1: 1)$ and $30 \mu \mathrm{l}$ of $2 \mathrm{M}$ formic acid. After being mixed and centrifuged, the upper layer was transferred to a conic tube for evaporation into a SpeedVac Concentrator (Sarant, Hicksville, NY, USA). Samples were reconstituted in $200 \mu \mathrm{l}$ methanol:10 mM ammonium acetate buffer, $\mathrm{pH} 8.5$ (70:30) before liquid chromatography/tandem mass spectrometry (LC/MS/MS) analysis. All extraction procedures were performed under low-light and lowtemperature conditions to minimise potential photo oxidation or thermal degradation of eicosanoid metabolites.

\section{$\mathrm{PGE}_{2}$ analysis by $\mathrm{LC} / \mathrm{MS} / \mathrm{MS}$}

$\mathrm{PGE}_{2}$ was quantified by LC/MS/MS using an API 3000 mass spectrometer (Applied Biosystem, Foster City, CA, USA) equipped with a Sciex turbo ion spray (AB Sciex, Toronto, Ontario, Canada) and Shimadzu pump and controller (Kyoto, Japan). Prostaglandins were chromatographically resolved using column Kromasil 100$3.5 \mathrm{C} 18150 \times 2.1 \mathrm{~mm}$ (Eka Chemicals AB, Brewster, NY, USA). A linear acetonitrile gradient from $45 \%$ to $90 \%$ for $12 \mathrm{~min}$ at a flow rate of $200 \mu \mathrm{l}$ per min was used to achieve baseline resolution for compounds of interest. The mobile phase consisted of water buffered with $0.05 \%$ of acetic acid (A) and acetonitrile $90 \%$ with acetic acid $0.05 \%$ (B). Injection volume was $10 \mu \mathrm{l}$ per samples, which were kept at $4{ }^{\circ} \mathrm{C}$ during the analysis. Individual products were detected using negative ionisation and the monitoring of the transition $\mathrm{m} / z \quad 351 \rightarrow 271$ for $\mathrm{PGE}_{2}$ and $355 \rightarrow 275$ for $\mathrm{PGE}_{2} \mathrm{~d}_{4}$ at collision energy of $-25 \mathrm{~V}$.

\section{COX-2 mRNA quantified by a semi-quantitative PCR (qPCR)}

3T3 fibroblasts $\left(2.5 \times 10^{5}\right)$ plated in six-well plates were incubated for $24 \mathrm{~h}$ in MEM medium supplemented with $10 \%$ FBS. The culture medium was then removed, cells rinsed twice with PBS and MEM medium supplemented with $0.1 \%$ BSA was added. The $3 \mathrm{~T} 3$ cells were irradiated $(5 \mathrm{~Gy})$ and the total RNA was extracted $24 \mathrm{~h}$ later. Total RNA extractions were performed on cell pellets with the Absolutely RNA Microprep Kit (Stratagene, La Jolla, CA, USA) as recommended by the manufacturer, except that DNAse treatments were done at $37^{\circ} \mathrm{C}$. RNA quality and presence of contaminating genomic DNA was verified as previously described (Brosseau et al, 2010). RNA integrity was assessed with an Agilent 2100 Bioanalyzer (Agilent Technologies, Mississauga, Ontario, Canada). Reverse transcription was performed on $2 \mu \mathrm{g}$ total RNA with Transcriptor reverse transcriptase, random hexamers, dNTPs (Roche Diagnostics, Laval, Quebec, Canada), and 10 units of RNAseOUT (Invitrogen, Burlington, Ontario, Canada) following the manufacturer's protocol in a total volume of $20 \mu \mathrm{l}$. All forward 
and reverse primers were individually resuspended to $20-100 \mu \mathrm{M}$ stock solution in Tris-EDTA buffer and diluted as a primer pair to $1 \mu \mathrm{M}$ in RNase DNase-free water (IDT, Coralville, IA, USA). Semi-qPCR reactions were performed in $10 \mu \mathrm{l}$ in 96-well plates on a Realplex2 thermocycler (Eppendorf, Mississauga, Ontario, Canada) with $5 \mu \mathrm{l}$ of $2 \times$ FastStart Universal SYBR Green Master mix (Roche Diagnostics), $10 \mathrm{ng}(3 \mu \mathrm{l}) \mathrm{cDNA}$ and $200 \mathrm{~nm}$ final $(2 \mu \mathrm{l})$ primer pair solutions. The following cycling conditions were used: $10 \mathrm{~min}$ at $95^{\circ} \mathrm{C} ; 50$ cycles: $15 \mathrm{~s}$ at $95^{\circ} \mathrm{C}, 30 \mathrm{~s}$ at $60^{\circ} \mathrm{C}$ and $30 \mathrm{~s}$ at $72{ }^{\circ} \mathrm{C}$. Relative expression levels were calculated using the qBASE framework (Hellemans et al, 2007) and the housekeeping genes $U B C, H P R T 1$ and GAPDH for mouse cDNA. Primer design and validation was evaluated as described elsewhere (Brosseau et al, 2010). In every qPCR run, a no template control was performed for each primer pair and these were consistently negative. Primer sequences: $C O X-2$; sense primer $5^{\prime}$-TGGTTTTGTGCTGGCCTGG TA-3', antisense primer $5^{\prime}$-TTCGAAGTTCAGCCTGGCAAGT- ${ }^{\prime}$; $U B C$; sense primer $5^{\prime}$-CGTCGAGCCCAGTGTTACCACCAAGAAG G-3', antisense primer $5^{\prime}$-CCCCCATCACACCCAAGAACAAGCAC AAG-3'; HPRT1; sense primer 5'-GCTTGCTGGTGAAAAGGACCT CTCGAAG- $3^{\prime}$, antisense primer $5^{\prime}$-CCCTGAAGTACTCATTATAGT CAAGGGCAT- $3^{\prime}$ GAPDH, sense primer $5^{\prime}$-TGACGTGCCGCCTGG AGAAA- $3^{\prime}$, antisense primer $5^{\prime}$-AGTGTAGCCCAAGATGCCCTTC AG-3'.

\section{Western blot analysis of COX-2}

The $3 \mathrm{~T} 3$ cells were irradiated ( $5 \mathrm{~Gy}$ ) and the whole cell protein lysates were prepared $24 \mathrm{~h}$ later with lysis buffer containing $50 \mathrm{~mm}$ Tris- $\mathrm{HCl}, \mathrm{pH} 7.5,150 \mathrm{~mm} \mathrm{NaCl}, 0.1 \%$ sodium dodecyl sulphate, $1 \%$ NP-40, 0.5\% Na-deoxycholate and 5 mM EDTA supplemented with the protein inhibitor cocktail Complete Mini, EDTA-free (Roche, Indianapolis, IN, USA). Cellular debris was cleared by centrifugation and supernatants were aliquoted and stored at $-80{ }^{\circ} \mathrm{C}$ for further use. Protein quantification assay was performed with a DC Protein Assay kit (Bio-Rad, Hercules, CA, USA). The protein extracts $(50 \mu \mathrm{g})$ were applied on a $12 \%$ polyacrylamide-SDS gel electrophoresed at $120 \mathrm{~V}$ during $3 \mathrm{~h}$ at $4{ }^{\circ} \mathrm{C}$ and transferred to a PVDF membrane (Millipore, Bedford, MA, USA) using the Mini Trans-Blot Cell (Bio-Rad) settled at $100 \mathrm{~V}$ for $1 \mathrm{~h}$. The membrane was blocked with $8 \%$ reconstituted skim milk powder in TBST solution $(10 \mathrm{~mm}$ Tris $-\mathrm{HCl} \mathrm{pH} 7.5$ containing $150 \mathrm{~mm} \mathrm{NaCl}$ and $0.05 \%$ Tween 20 ). The blots were incubated with COX-2 antibody (Cayman) in blocking solution overnight at $4{ }^{\circ} \mathrm{C}$. After washing with TBST, horseradish peroxidase-conjugated secondary antibodies (AbD Serotec, Raleigh, NC, USA) (1:10000 dilution in TBST) were applied and the blots developed by the Enhanced Chemiluminescence Detection System (Perkin Elmer, Waltham, MA, USA). Levels of beta-actin immunocomplexes were used as an internal standard for equal loading.

\section{Statistical analysis}

The data are expressed as the mean \pm s.d. Statistical analysis was performed using the Student's $t$-test, and a value of $P<0.05$ was considered significant.

\section{RESULTS}

Irradiated 3T3 fibroblasts increases the invasion but not the migration of breast cancer cells

Irradiated 3T3 fibroblasts plated in the lower compartment of invasion chambers were used as chemoattractant to determine whether they can increase the invasiveness of non-irradiated breast cancer cells plated in the upper compartment of invasion chambers. When the non-irradiated MDA-MB-231 cells were plated right after irradiation of the $3 \mathrm{~T} 3$ fibroblasts in the invasion chamber, their invasiveness increased by 2.6 -fold \pm 0.7 (Figure $1 \mathrm{~A}$, $T=0 \mathrm{~h}, P=0.016)$. Irradiated $3 \mathrm{~T} 3$ cells further stimulated cancer cell invasion when the invasion assay began $24 \mathrm{~h}$ after irradiation resulting in a larger number of MDA-MB-231 cells crossing the layer of Matrigel (Figure 1A, $T=24 \mathrm{~h}, 5.8$-fold $\pm 1.4, P=0.01$ ). It is noteworthy that extending the incubation time to $24 \mathrm{~h}$ before to start the invasion assay did not significantly increase the invasiveness of MDA-MB-231 cells when the 3T3 cells were not irradiated (Figure 1A, 1.9-fold $\pm 0.8, T=24 \mathrm{~h}, P=0.06$ ).

The effect of irradiated fibroblasts on the migration of the breast cancer cell MDA-MB-231 was assessed with migration chambers, which were similar to the invasion chamber but without the layer of Matrigel. The MDA-MB-231 cells were plated in the upper compartment $24 \mathrm{~h}$ after the irradiation. As shown on Figure $1 \mathrm{~B}$, the migration capacity of the MDA-MB-231 cells was not significantly affected by the irradiated fibroblasts compared with the nonirradiated control (ratio $5 \mathrm{~Gy} / 0 \mathrm{~Gy}=0.98 \pm 0.19, P$-value $=0.91$; Figure 1B).

\section{COX-2 inhibitor prevents radiation-enhancement of invasion}

To determine the potential role of COX-2 in radiation-enhancement of cancer cells invasion, the specific COX-2 inhibitor NS-398
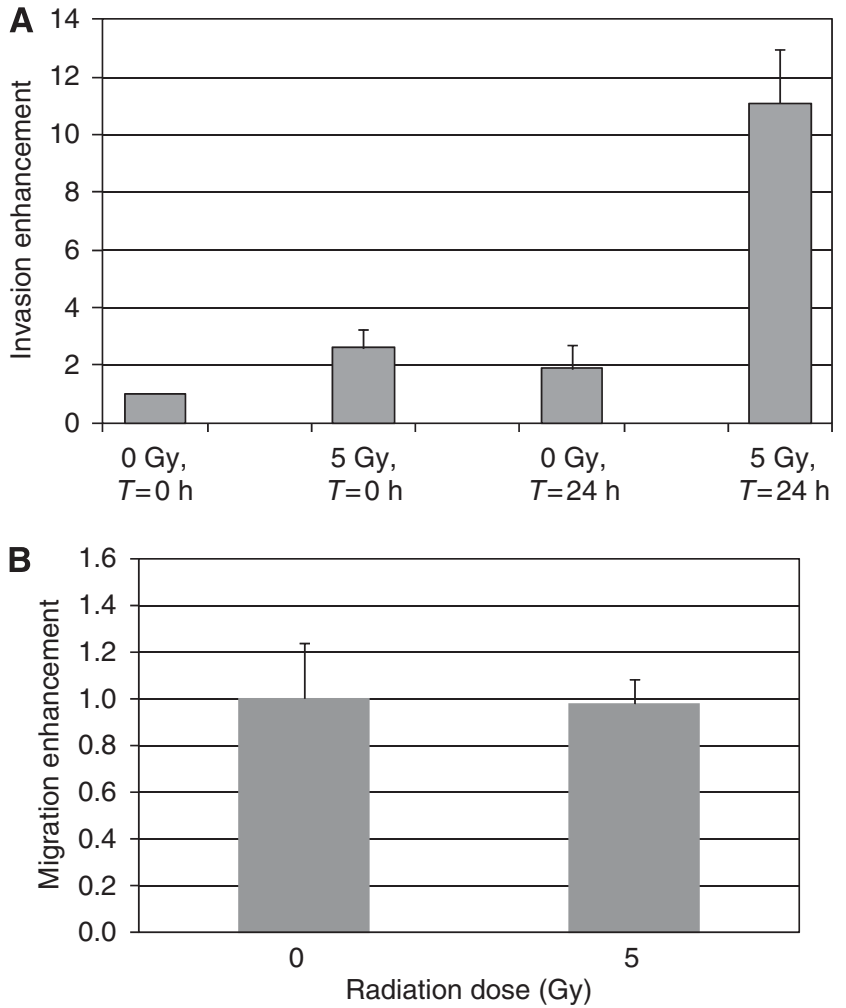

Figure I Irradiation of 3T3 fibroblasts increases the invasiveness of nonirradiated MDA-MB-23I cells. (A) 3T3 fibroblasts plated in the lower compartment of invasion chambers were irradiated at $5 \mathrm{~Gy}$. Non-irradiated MDA-MB-23I cells were plated in the upper compartment of the invasion chambers either immediately after the irradiation, or $24 \mathrm{~h}$ later. The numbers of MDA-MB-23I cells, which have migrated through the layer of Matrigel were counted $24 \mathrm{~h}$ later. (B) $3 \mathrm{~T} 3$ fibroblasts irradiated at $5 \mathrm{~Gy}$ were plated in the lower compartment of migration chambers, which were not coated with a layer of Matrigel. Non-irradiated MDA-MB-23I cells were plated in the upper compartment $24 \mathrm{~h}$ later. The numbers of MDAMB-23 I cells, which have crossed the porous filter were counted $24 \mathrm{~h}$ later. (A) 0 Gy $T=0 \mathrm{~h}$ vs $5 \mathrm{~Gy} T=0 \mathrm{~h}, P=0.0 \mathrm{l6}$; $0 \mathrm{~Gy} T=0 \mathrm{~h}$ vs $0 \mathrm{~Gy} T=24 \mathrm{~h}$, $P=0.06$; 0 Gy $T=24 \mathrm{~h}$ vs $5 \mathrm{~Gy} T=24 \mathrm{~h}, P=0.0 \mathrm{l}$. (B) 0 vs $5 \mathrm{~Gy}, P=0.91$ 


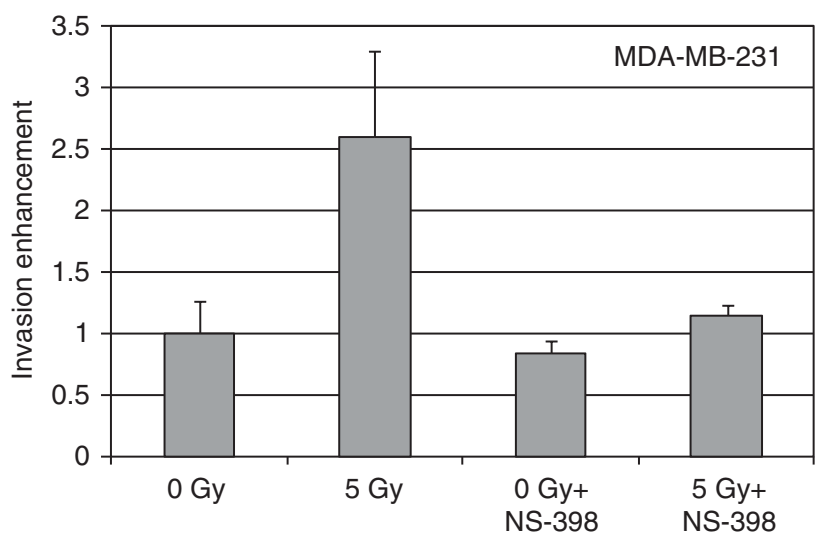

Figure 2 Prevention of radiation-enhancement of cancer cells invasion by a COX-2 inhibitor. The specific COX-2 inhibitor NS-398 (10 $\mu \mathrm{M})$ was added to the $3 \mathrm{~T} 3$ cells I $\mathrm{h}$ before their irradiation (5 Gy). The invasion assays with the non-irradiated MDA-MB-23I cells were then repeated as previously described. 0 vs $5 \mathrm{~Gy}, P=0.0$ I; 0 vs $0 \mathrm{~Gy}+\mathrm{NS}-398, P=0.83 ; 0$ vs 5 Gy + NS-398, $P=0.51$

Table I Production of $\mathrm{PGE}_{2}$ by MDA-MB-23I cells and irradiated 3T3 fibroblasts

$$
\mathrm{PGE}_{2}\left(\mathrm{pg} \mathrm{ml}^{-1}\right)^{\mathrm{a}}
$$

\section{T3 cells}

Dose (Gy)

Without NS-398 With NS-398

\begin{tabular}{lllc}
\hline 0 & $1303( \pm 234)^{\mathrm{b}}$ & $0.00^{\mathrm{b}}$ & $7( \pm 3)$ \\
5 & $1151( \pm 127)$ & 0.00 & $\mathrm{ND}$ \\
\hline
\end{tabular}

Abbreviations: $\mathrm{BSA}=$ bovine serum albumin; $\mathrm{LC} / \mathrm{MS} / \mathrm{MS}=$ liquid chromatography/ tandem mass spectrometry; $\mathrm{ND}=$ not determined; $\mathrm{PGE}_{2}=$ prostaglandin $\mathrm{E} 2 .{ }^{\mathrm{a}} \mathrm{As}$ assessed by LC/MS/MS. Cells irradiated in 0.1\% BSA. 'Without NS-398: $n=6$, $P$-value $=0.30$. With NS-398: $n=3, P$-value $=$ not applicable

was added to the $3 \mathrm{~T} 3$ fibroblasts $1 \mathrm{~h}$ before their irradiation. Invasion assays were then repeated with the MD-MB-231 cells (Figure 2). The COX-2 inhibitor completely prevented radiationenhancement of cancer cells invasion (ratio 5 Gy+ NS-398/ $0 \mathrm{~Gy}=1.15$-fold $\pm 0.09, P=0.51$ ). Supporting the role of $\mathrm{PGE}_{2}$, addition of the COX-2 inhibitor NS-398 to the 3 T3 cells resulted in a drastic reduction of $\mathrm{PGE}_{2}$ production (Table 1). The effect of NS-398 on cancer cell invasion was specific to the irradiated fibroblasts because this inhibitor did not affect the invasion capacity of control MDA-MB-231 cells incubated with nonirradiated 3T3 fibroblasts (Figure 2).

\section{Effect of $\mathrm{PGE}_{2}$ on cancer cell invasion}

The major product of COX-2 is the prostaglandin $\mathrm{PGE}_{2}$. This prostaglandin was added to the MDA-MB-231 cells plated in the invasion chamber to determine whether it can increase the invasion ability of these cancer cells (Figure 3A). A biphasic effect of $\mathrm{PGE}_{2}$ was observed. At a concentration of $10 \mathrm{pg} \mathrm{ml}^{-1}, \mathrm{PGE}_{2}$ stimulated the invasiveness of the breast cancer cells MDA-MB-231 by 1.8 -fold $\pm 0.33 \quad(P=0.02)$, while exposure to the higher concentration $\left(1000 \mathrm{pg} \mathrm{ml}^{-1}\right)$ did not significantly modify the invasiveness of the MDA-MB-231 cells $(0.9$-fold $\pm 0.1, P=0.21)$.

\section{Stimulation of MMP-2 by PGE $_{2}$}

The MDA-MB-231 cells plated on a layer of Matrigel, as occurred in the invasion chamber, were incubated with $\mathrm{PGE}_{2}$ for $24 \mathrm{~h}$. The
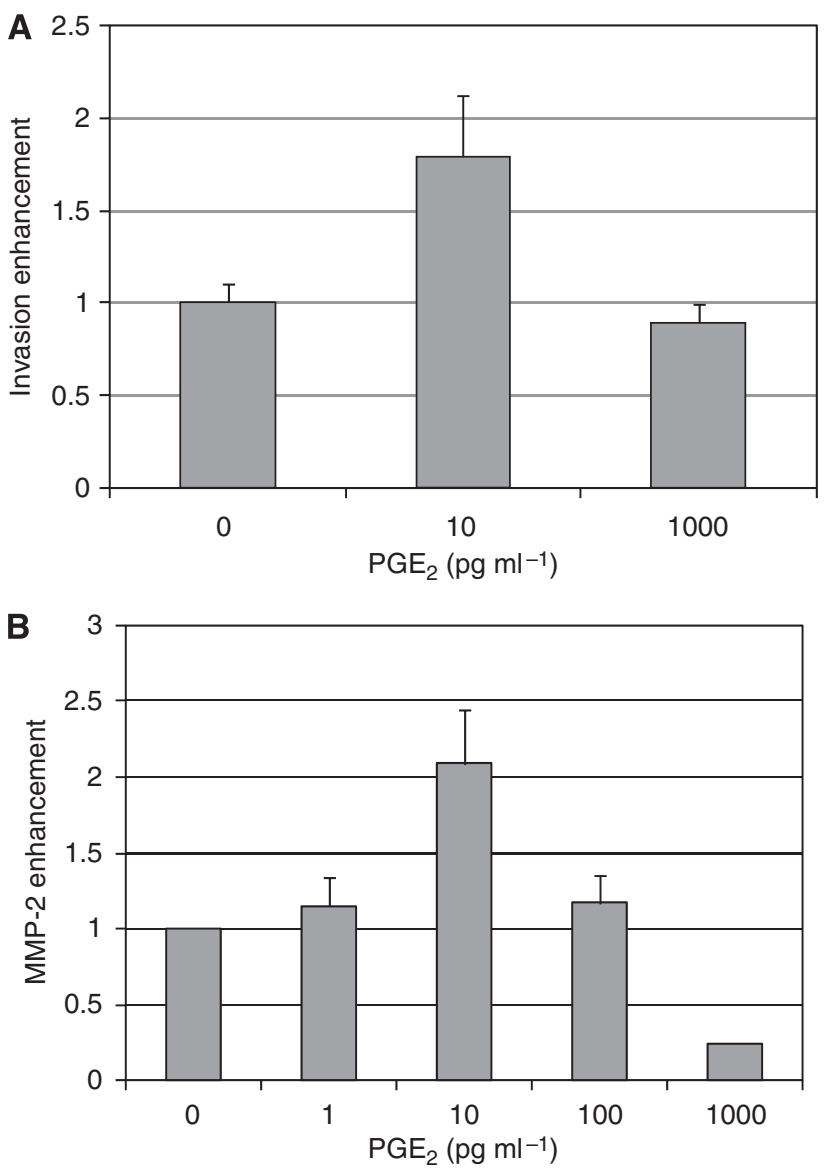

Figure 3 Modulation by $\mathrm{PGE}_{2}$ of invasion capacity of MDA-MB-23। cells and the release of MMP-2. (A) PGE 2 was added to the MDA-MB-23I cells plated in the upper compartment of the invasion chambers. The invasion assay was then repeated as previously described. (B) PGE 2 was added at the concentration indicated to MDA-MB-23I cells plated on a layer of Matrigel. The conditioned media containing the MMP-2 was analysed $24 \mathrm{~h}$ later by zymography gel. (A) $0 \mathrm{vs} 10 \mathrm{pg} \mathrm{ml} l^{-1}, P=0.02 ; 0 \mathrm{vs} 1000 \mathrm{pg} \mathrm{ml}^{-1}$, $P=0.21$. (B) 0 vs $10 \mathrm{pg} \mathrm{ml}^{-1}, P=0.026$.

conditioned media was analysed for its content in MMP-2 by gel zymography (Figure $3 \mathrm{~B}$ ). A biphasic effect of $\mathrm{PGE}_{2}$ on the release of the protease MMP-2 by MDA-MB-231 cells was measured. The highest stimulation obtained at a concentration of $10 \mathrm{pg} \mathrm{ml}^{-1}$ resulted in a 2.1 -fold $\pm 0.45(P=0.026)$ increase in MMP-2 production. Conversely, higher concentration of $\mathrm{PGE}_{2}$ $\left(1000 \mathrm{pg} \mathrm{ml}^{-1}\right)$ has decreased the release of MMP-2 from the MDA-MB-231 cells.

\section{Effect of radiation on COX-2 mRNA expression and production of $\mathrm{PGE}_{2}$}

The $3 \mathrm{~T} 3$ fibroblasts were irradiated at $5 \mathrm{~Gy}$ and $24 \mathrm{~h}$ later the level of COX-2 mRNA was determined by a semi-qPCR, while the quantity of COX-2 protein was estimated with a western blot assay. As shown on Table 2, irradiation of the 3T3 cells enhanced the expression of COX-2 by 1.45 -fold compared with the nonirradiated 3T3 cells $(P$-value $=0.019)$. Regarding the COX-2 protein, a small but not significant increase was measured. Supporting that radiation did not significantly modify the COX-2 activity, no increase in $\mathrm{PGE}_{2}$ production from the irradiated 3T3 cells was measured by a LC/MS/MS analysis performed $24 \mathrm{~h}$ after radiation exposure (Table 1 ). 
Table 2 Expression of COX-2 in irradiated 3T3 fibroblasts

Enhancement ratio: 5 Gy/0 Gy

\begin{tabular}{lc}
\hline COX-2 mRNA $^{\mathbf{a}}$ & COX-2 $^{\text {protein }^{\mathbf{b}}}$ \\
\hline $1.45( \pm 0.09)^{c}$ & $1.25( \pm 0.32)^{c}$ \\
\hline
\end{tabular}

Abbreviations: $C O X-2$ = cyclooxygenase-2; $\mathrm{QPCR}=$ quantitative PCR. ${ }^{\mathrm{a}} \mathrm{As}$ assessed by a semi-qPCR. bAs assessed by western blot. ${ }^{c} n=3$. COX-2 mRNA, $P$-value $=0.019$. COX-2 protein, $P$-value $=0.14$

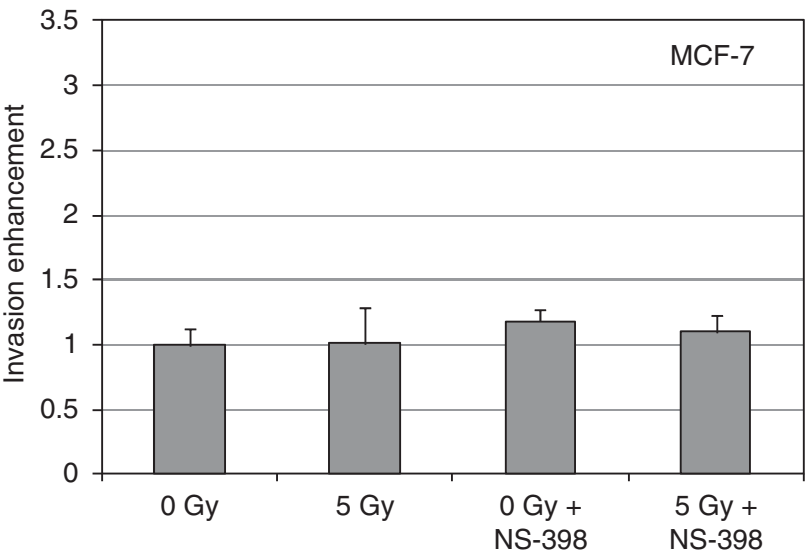

Figure 4 Effect of irradiated 3T3 fibroblasts on the invasiveness of MCF-7 cells. 3 T3 fibroblasts plated in the lower compartment of invasion chambers were irradiated at 5 Gy. Non-irradiated MDA-MB-23I cells were plated in the upper compartment of the invasion chambers $24 \mathrm{~h}$ later. The numbers of MDA-MB-23I cells, which have migrated through the layer of Matrigel were counted $24 \mathrm{~h}$ later. 0 vs $5 \mathrm{~Gy}, P=0.01$.

\section{Role of ER}

Ability of irradiated 3T3 fibroblasts to enhance the invasion of the MDA-MB-231 ER(-) was compared with breast cancer cell line MCF-7 ER $(+)$ to assess the role of ER in radiation-enhancement of cancer cell invasion. The invasion assays demonstrated that while an important stimulation was measured with the MDA-MB$231 \mathrm{ER}(-)$ cells (Figure 2), the invasiveness of the MCF-7 ER( + ) was not increased by the irradiated $3 \mathrm{~T} 3$ fibroblasts (Figure 4). An incubation with the COX-2 inhibitor NS-398 $1 \mathrm{~h}$ before to start the invasion assay did modify the invasiveness of the MCF-7 incubated with irradiated and non-irradiated 3T3 fibroblasts (Figure 4).

\section{Association with MT1-MMP}

In a previous study, we have quantified the expression of the MT1 - MMP by a semi-quantification PCR in the breast cancer cell lines MDA-MB-231 and MCF-7 (Paquette et al, 2007). Although a high level MT1-MMP mRNA was found for the MDA-MB-231 cells, no significant quantity of this metalloproteinase was measured in the MCF-7 cells. To further assess the role of MT1MMP in radiation-enhancement of cancer cell invasion, an antiMT1-MMP was added to the MDA-MB-231 cells plated in the invasion chamber (Figure 5). A reduction of the invasiveness was observed when both the non-irradiated and the irradiated 3T3 fibroblasts were used as chemioattractant $(0 v s 0 \mathrm{~Gy}+$ anti-MT1 MMP, $P=0.03 ; 5$ vs $5 \mathrm{~Gy}+$ anti-MT1-MMP, $P<0.01)$. It is noteworthy that addition of the anti-MT1-MMP resulted to a similar level of invasion for the MDA-MB-231 cells incubated with either the irradiated or non-irradiated $3 \mathrm{~T} 3$ fibroblasts $(0 \mathrm{~Gy}+$ antiMT1-MMP vs 5 Gy + anti-MT1 - MMP, $P=0.39$ ).

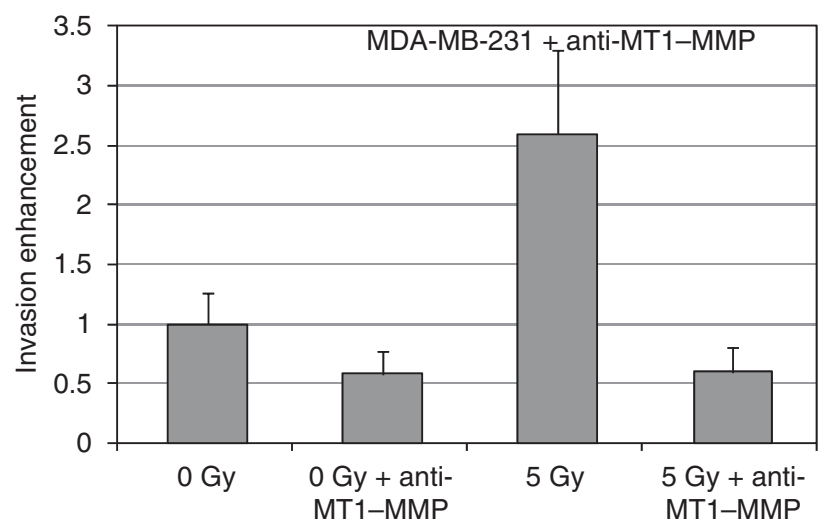

Figure 5 Reduction of the invasiveness of the MDA-MB-23। cells with the anti-MTI-MMP. Anti-MTI-MMP was added to the MDA-MB-23I cells plated in the upper compartment of the invasion chambers. The invasion assay was then repeated as previously described. 0 vs 0 Gy + antiMTI -MMP, $P=0.03 ; 5$ vs 5 Gy + anti-MTI $-M M P, P<0.01 ; 0$ Gy + antiMTI-MMP vs $5 \mathrm{~Gy}+$ anti-MTI-MMP, $P=0.39$.

\section{DISCUSSION}

Protocols for treating breast tumours by radiotherapy frequently included the whole breast and a large fraction of the chest to reach the axillaries and supraclavicular lymphatic nodes. Therefore, contrary to other cancers, a large number of normal cells received a significant radiation dose. As fibroblasts are normal component of the breast and their potential role in cancer progression has already been suggested (Camps et al, 1990; Ohuchida et al, 2004), their involvement in radiation-enhancement of breast cancer cell invasion was assessed.

Our study demonstrated that irradiation of fibroblasts increases the invasiveness of breast cancer cells MDA-MB-231 in an in vitro model, without affecting their ability to migrate. The clinical impact of this finding could be important because the interactions between cancer cells and surrounding stromal fibroblasts have been suggested to have a critical role in tumour invasion and metastasis (Camps et al, 1990; Ohuchida et al, 2004). Supporting the importance of fibroblasts, it was reported that a co-culture with non-irradiated fibroblasts significantly increased the invasiveness of pancreatic cancer cells, which was even further accelerated by a co-culture with irradiated fibroblasts (Ohuchida et al, 2004). More saliently, irradiated co-cultures of the low invasive colorectal cancer cell line LoVo with fibroblasts dramatically increased the invasiveness of these cancer cells (Speake et al, 2005).

To gain insights into the mechanisms involved in radiationenhancement of cancer cell invasion, the potential role of COX-2 was assessed. This enzyme was chosen because it was associated with clinically more aggressive disease in addition to a decrease in survival of cancer patients (Gaffney et al, 2001; O'Connor et al, 2004). Making the link with cancer aggressiveness, Larkins et al (2006) have observed that COX-2 can stimulate breast cancer cell motility, invasion and MMP expression (Larkins et al, 2006). Furthermore, COX-2 is a key enzyme in the inflammatory response, which is induced by radiotherapy in almost all breast cancer patients. Therefore, as COX-2 expression correlates with tumour aggressiveness, adverse prognosis and that its expression can be stimulated by radiation, it follows that inhibition of COX-2 may have a therapeutic value.

In our study, inhibition of COX-2 by NS-398 completely prevented the enhancement of MDA-MB-231 cancer cell invasion induced by irradiated fibroblasts. As no $\mathrm{PGE}_{2}$ was measured after the addition of NS-398, this supports the activity of COX-2 was completely inhibited. It is interesting to note that invasiveness of 
the MDA-MB-231 cells incubated with the NS-398 came back to the same level measured in the assays done with non-irradiated fibroblasts. These results suggest that other factors independent of COX-2 activity also contributed to the invasion of these cancer cells, and they could work in association with irradiated fibroblasts to further enhance the invasion of breast cancer cell invasion.

In order to continue this study in an animal model, we have shown that a local irradiation before the implantation of breast cancer cells increased their invasiveness in surrounding normal tissue. This radiation-enhancement of cancer cell invasion was associated with an increase in COX-2 and MMP-2 expression (Lemay et al, 2011; Paquette et al, 2008). It remains to be determined whether a COX-2 inhibitor administrated in an animal model would prevent radiation-enhancement of cancer cell invasion.

COX-2 is a key enzyme induced during the inflammatory response, which produces the prostaglandin $\mathrm{PGG}_{2}$, a precursor of at least 5 prostaglandins and some thromboxanes. Among them, $\mathrm{PGE}_{2}$ was frequently associated to cancer progression. The $3 \mathrm{~T} 3$ fibroblasts used in our study already secreted large among of $\mathrm{PGE}_{2}$ before their irradiation. Therefore, it might be not surprising that radiation could not further increase its production of $\mathrm{PGE}_{2}$. On the other hand, we showed that the breast cancer cell MDA-MB-231 released about 180 times less $\mathrm{PGE}_{2}$ than the $3 \mathrm{~T} 3$ fibroblasts. We proposed that incubation of the MDA-MB-231 cells with the 3T3 fibroblasts in the invasion chamber produced a conditioned culture media where the final concentration of $\mathrm{PGE}_{2}$ results in an enhancement of cancer cell invasion.

The role of $\mathrm{PGE}_{2}$ in the invasion of MDA-MB-231 cells was associated to the concentration used during the invasion assay. Added at $10 \mathrm{pg} \mathrm{ml}^{-1}$ to the MDA-MB-231 breast cancer cells, $\mathrm{PGE}_{2}$ has increased cancer cell invasion and the release of MMP-2. However, a reduction of cancer cell invasiveness and MMP-2 released from the MDA-MB-231 cells were observed at a concentration of $1000 \mathrm{pg} \mathrm{ml}^{-1} \mathrm{PGE}_{2}$. A similar biphasic effect of $\mathrm{PGE}_{2}$ was reported for the proliferation of fibroblasts and it was associated to the subtype of $\mathrm{PGE}_{2}$ receptors (EP1-4) activated (Timoshenko et al, 2003; White et al, 2008). Promitogenic effects of mid-range concentrations of $\mathrm{PGE}_{2}$ were mimicked by the EP3selective agent (sulprostone) identifying EP3 as the key proliferative stimulatory receptor. Conversely, at higher concentrations of $\mathrm{PGE}_{2}$, inhibition of fibroblast proliferation was associated to the EP2 receptor (White et al, 2008). As the MDA-MB-231 breast cancer cells express all the four subtypes of $\mathrm{PGE}_{2}$ receptors, it remains to be determined whether the biphasic effect of $\mathrm{PGE}_{2}$ on their invasiveness and release of MMP-2 could be related to activation of different subtypes of its receptor.

We also assess the potential role of ERs in radiation-enhancement of cancer cell invasion. Oestrogen receptor has an important role in breast cancer progression. They are overexpressed in human breast cancers and associated with differentiated tumours and with a more favourable prognosis than ER(-) tumours, which are associated with an invasion behaviour and a shorter overall survival (Chen et al, 2002). Paradoxically, ER mediate the mitogenic action of oestrogens in human breast cancer cells, which suggests that locally produced oestrogen may have a role in stimulating neoplastic growth and development (Bulun et al, 1993). The promoter role of oestrogens in breast cancer has been evidenced by epidemiological studies indicating an increased incidence in women with prolonged exposure to oestrogens and a drastic decrease in incidence in women having nonfunctional ovaries (Pike et al, 1983).

Our study demonstrated that radiation-enhancement of breast cancer cell invasion was not associated with the ER. Although irradiated fibroblasts stimulated the invasiveness of MDA-MB-231 cells that are $\mathrm{ER}(-)$, no enhancement was measured with the $\mathrm{ER}(+)$ cell line MCF-7. Nevertheless, the potential role of oestradiol in the invasiveness of breast cancer cells should be further assessed because COX-2 can be associated with the production of oestradiol. Indeed, oestradiol is biosynthesised from androgens by the cytochrome P450 enzyme complex called aromatase, the product of the CYP19 gene (Simpson et al, 1994). Although the levels of CYP19 gene expression remained relatively constant in breast cancer tissue, increased level of CYP19 mRNA were found in advanced breast cancer tissue showing signs of invasion (Diaz-Cruz and Brueggemeier, 2006). A strong positive relationship was demonstrated between COX-2 and aromatase mRNA expression, and lends further support to the hypothesis that COX-2 is an upregulator of aromatase in breast tissue (Salhab et al, 2007). Thus, $\mathrm{PGE}_{2}$ produced via COX-2 may act locally in paracrine and autocrine manner to increase the biosynthesis of oestrogen by aromatase in hormone-dependent breast cancer development (Diaz-Cruz and Brueggemeier, 2006). Supporting the role of COX-2, studies have shown that COX inhibitors decrease aromatase activity in breast cancer cells and this effect starts at the transcriptional level. The precise role of COX-2 in the invasion of cancer cell ER $(+)$ remains to be further investigated because COX-2 expression was also inversely associated with ER and it significantly correlated with worse survival (Zerkowski et al, 2007).

To further understand the role of oestrogens, we have previously studied their role in breast cancer cell invasion (Paquette et al, 2005). In this study, the ability of oestrogens to enhance the invasiveness of breast cancer cells was correlated to a subgroup of oestrogens, the hydroxyoestrogens. These oestrogens have been studied because the oestrogen metabolism is altered in malignant breast tumours that favour the accumulation of hydroxyoestradiol, which are known to generate free radicals (Abul-Hajj et al, 1988; Liehr, 2000; Paquette et al, 2001; Thibodeau et al, 2002). Using invasion chambers, oestradiol could not enhance the invasiveness of the MDA-MB-231 breast cancer cells. On the other hand, an important increase in breast cancer cell invasiveness was observed after adding the 4-hydroxyoestradiol. This increase was associated to the ability of 4-hydroxyoestradiol to generate free radicals, which can activate the MMP-2 and MMP-9 by removing their propeptide (Paquette et al, 2003). Therefore, it could be relevant to determine whether hydroxyoestrogens accumulated in breast tumours could increase the radiationenhancement of cancer cell invasion in breast cancer cells ER( + ) and $\operatorname{ER}(-)$.

Pro-MMP can also be activated by an enzymatic pathway. Indeed, conversion of inactive proMMP-2 into active MMP-2 can proceed through the formation of the complex proMMP-2/MT1 MMP/TIMP-2. This complex matures after binding to $\alpha_{\mathrm{v}} \beta_{3}$ integrin at the cancer cell surface, which concentrates the active MMP-2 at the migrating front (Brooks et al, 1996). Supporting the role of MT1-MMP, we demonstrated that the enhancement of MDA-MB231 cell invasion induced by irradiated fibroblasts was prevented by incubating these cancer cells with a MT1-MMP antibody. A similar prevention of cancer cell invasion with a MT1-MMP antibody was previously reported by our team when MDA-MB-231 cells were incubated in invasion chambers containing irradiated Matrigel (artificial extracellular matrix) (Paquette et al, 2006). These two studies support that expression of MT1 - MMP by breast cancer cells is required for the enhancement of their invasiveness induced by irradiation.

\section{CONCLUSION}

Radiation-enhancement of breast cancer cell invasion induced by irradiated 3T3 fibroblasts is not dependant on the ER status, but rather on the expression of MT1-MMP. This adverse effect of radiation can be prevented by a COX-2 inhibitor. To better understand the involvement $\mathrm{PGE}_{2}$ in this process, the specific role of the four subtypes of $\mathrm{PGE}_{2}$ receptor should be assessed. 


\section{ACKNOWLEDGEMENTS}

This research project was funded by the Canadian Institutes of Health Research, Grant MOP 184671. Dr Benoit Paquette and Dr Rachel Bujold are members of the FRSQ-funded Centre de recherche clinique Étienne-LeBel. We thank the RNomics Platform at the Université de Sherbrooke for the qPCR analyses.

\section{REFERENCES}

Abul-Hajj YJ, Thijssen JH, Blankenstein MA (1988) Metabolism of estradiol by human breast cancer. Eur J Cancer Clin Oncol 24: 1171-1178

Brooks PC, Stromblad S, Sanders LC, von Schalscha TL, Aimes RT, Stetler-Stevenson WG, Quigley JP, Cheresh DA (1996) Localization of matrix metalloproteinase MMP-2 to the surface of invasive cells by interaction with integrin apha v beta 3. Cell 85: 683-693

Brosseau JP, Lucier JF, Lapointe E, Durand M, Gendron D, Gervais-Bird J, Tremblay K, Perreault JP, Elela SA (2010) High-throughput quantification of splicing isoforms. RNA 16: $442-449$

Bulun SE, Price TM, Aitken J, Mahendroo MS, Simpson ER (1993) A link between breast cancer and local estrogen biosynthesis suggested by quantification of breast adipose tissue aromatase cytochrome P450 transcripts using competitive polymerase chain reaction after reverse transcription. J Clin Endocrinol Metab 77: 1622-1628

Camps JL, Chang SM, Hsu TC, Freeman MR, Hong SJ, Zhau HE, von Eschenbach AC, Chung LW (1990) Fibroblast-mediated acceleration of human epithelial tumor growth in vivo. Proc Natl Acad Sci USA 87: $75-79$

Chen SC, Chen MF, Hwang TL, Chao TC, Lo YF, Hsueh S, Chang JT, Leung WM (2002) Prediction of supraclavicular lymph node metastasis in breast carcinoma. Int J Radiat Oncol Biol Phys 52: 614-619

De Conno F, Ventafridda V, Saita L (1991) Skin problems in advanced and terminal cancer patients. J Pain Symptom Manage 6: 247-256

Diaz-Cruz ES, Brueggemeier RW (2006) Interrelationships between cyclooxygenases and aromatase: unraveling the relevance of cyclooxygenase inhibitors in breast cancer. Anticancer Agents Med Chem 6: $221-232$

Fillmore HL, VanMeter TE, Broaddus WC (2001) Membrane-type matrix metalloproteinases (MT-MMPs): expression and function during glioma invasion. J Neurooncol 53: $187-202$

Gaffney DK, Holden J, Davis M, Zempolich K, Murphy KJ, Dodson M (2001) Elevated cyclooxygenase-2 expression correlates with diminished survival in carcinoma of the cervix treated with radiotherapy. Int $J$ Radiat Oncol Biol Phys 49: 1213-1217

Hellemans J, Mortier G, De Paepe A, Speleman F, Vandesompele J (2007) qBase relative quantification framework and software for management and automated analysis of real-time quantitative PCR data. Genome Biol 8: R19

Holland R, Veling SH, Mravunac M, Hendriks JH (1985) Histologic multifocality of Tis, T1-2 breast carcinomas. Implications for clinical trials of breast-conserving surgery. Cancer 56: 979-990

Kaliski A, Maggiorella L, Cengel KA, Mathe D, Rouffiac V, Opolon P, Lassau N, Bourhis J, Deutsch E (2005) Angiogenesis and tumor growth inhibition by a matrix metalloproteinase inhibitor targeting radiationinduced invasion. Mol Cancer Ther 4: 1717-1728

Lagios MD, Westdahl PR, Rose MR (1981) The concept and implications of multicentriciy in breast carcinoma. In Pathology Annual, Sommers S, Rosen P (eds). Appleton-Century-Crofts: New York

Larkins TL, Nowell M, Singh S, Sanford GL (2006) Inhibition of cyclooxygenase-2 decreases breast cancer cell motility, invasion and matrix metalloproteinase expression. BMC Cancer 6: 181

Lemay R, Archambault M, Tremblay L, Bujold R, Lepage M, Paquette B (2011) Irradiation of normal mouse tissue increases the invasiveness of mammary cancer cells. Int J Radiat Biol 87: 472-482

Leppa S, Saarto T, Vehmanen L, Blomqvist C, Elomaa I (2004) A high serum matrix metalloproteinase-2 level is associated with an adverse prognosis in node-positive breast carcinoma. Clin Cancer Res 10: $1057-1063$

Liang L, Hu D, Liu W, Williams JP, Okunieff P, Ding I (2003) Celecoxib reduces skin damage after radiation: selective reduction of chemokine and receptor mRNA expression in irradiated skin but not in irradiated mammary tumor. Am J Clin Oncol 26: S114-S121

Liehr JG (2000) Is estradiol a genotoxic mutagenic carcinogen? Endocr Rev 21: $40-54$

Lind P (2006) Clinical relevance of pulmonary toxicity in adjuvant breast cancer irradiation [comment]. Acta Oncologica 45: 13-15
Nystrom J, Geladi P, Lindholm-Sethson B, Rattfelt J, Svensk AC, Franzen L (2004) Objective measurements of radiotherapy-induced erythema. Skin Res Technol 10: $242-250$

O'Connor JK, Avent J, Lee RJ, Fischbach J, Gaffney DK (2004) Cyclooxygenase-2 expression correlates with diminished survival in invasive breast cancer treated with mastectomy and radiotherapy. Int $J$ Radiat Oncol Biol Phys 58: $1034-1040$

Ohuchida K, Mizumoto K, Murakami M, Qian LW, Sato N, Nagai E, Matsumoto K, Nakamura T, Tanaka M (2004) Radiation to stromal fibroblasts increases invasiveness of pancreatic cancer cells through tumor-stromal interactions. Cancer Res 64: 3215-3222

Paquette B, Baptiste C, Therriault H, Arguin G, Plouffe B, Lemay R (2006) Irradiation of basement membrane enhances the invasiveness of breast cancer cells. Reasons for Hope 2006, Canadian Breast Cancer Research Initiative (CBCRI) 4th National Scientific Conference, 6-8 May, Montreal

Paquette B, Baptiste C, Therriault H, Arguin G, Plouffe B, Lemay R (2007) In vitro irradiation of basement membrane enhances the invasiveness of breast cancer cells. Br J Cancer 97: 1505-1512

Paquette B, Bisson M, Baptiste C, Therriault H, Lemay R, Cantin AM (2005) Invasiveness of breast cancer cells MDA-MB-231 through extracellular matrix is increased by the estradiol metabolite 4-hydroxyestradiol. Int J Cancer 113: $706-711$

Paquette B, Bisson M, Therriault H, Lemay R, Pare M, Banville P, Cantin AM (2003) Activation of matrix metalloproteinase- 2 and -9 by 2- and 4-hydroxyestradiol. J Steroid Biochem Mol Biol 87: 65-73

Paquette B, Cantin AM, Kocsis-Bedard S, Barry S, Lemay R, Jay-Gerin JP (2001) In vitro generation of peroxynitrite by 2 - and 4-hydroxyestrogens in the presence of nitric oxide. Chem Res Toxicol 14: 547-554

Paquette B, Lemay R, Pépin C, Tremblay L, Lepage M (2008) Invasiveness of breast cancer cell enhanced by radiation. Radiation Research Society 54th Annual Meeting, Boston, MA, USA

Park CM, Park MJ, Kwak HJ, Lee HC, Kim MS, Lee SH, Park IC, Rhee CH, Hong SI (2006) Ionizing radiation enhances matrix metalloproteinase-2 secretion and invasion of glioma cells through Src/epidermal growth factor receptor-mediated p38/Akt and Phosphatidylinositol 3-kinase/Akt signaling pathways. Cancer Res 66: $8511-8519$

Pike MC, Krailo MD, Henderson BE, Casagrande JT, Hoel DG (1983) 'Hormonal' risk factors, 'breast tissue age' and the age-incidence of breast cancer. Nature 303: $767-770$

Qian LW, Mizumoto K, Urashima T, Nagai E, Maehara N, Sato N, Nakajima M, Tanaka M (2002) Radiation-induced increase in invasive potential of human pancreatic cancer cells and its blockade by a matrix metalloproteinase inhibitor, CGS27023. Clin Cancer Res 8: 1223-1227

Rofstad EK, Mathiesen B, Galappathi K (2004) Increased metastatic dissemination in human melanoma xenografts after subcurative radiation treatment: radiation-induced increase in fraction of hypoxic cells and hypoxia-induced up-regulation of urokinase-type plasminogen activator receptor. Cancer Res 64: 13-18

Rooprai HK, McCormick D (1997) Proteases and their inhibitors in human brain tumours: a review. Anticancer Res 17: 4151-4162

Salhab M, Singh-Ranger G, Mokbel R, Jouhra F, Jiang WG, Mokbel K (2007) Cyclooxygenase-2 mRNA expression correlates with aromatase expression in human breast cancer. J Surg Oncol 96: 424-428

Schmitz KJ, Callies R, Wohlschlaeger J, Kimmig R, Otterbach F, Bohr J, Lee HS, Takeda A, Schmid KW, Baba HA (2006) Overexpression of cyclooxygenase- 2 is an independent predictor of unfavourable outcome in node-negative breast cancer, but is not associated with protein kinase B (Akt) and mitogen-activated protein kinase (ERK1/2, p38) activation or with Her-2/neu signalling pathways. J Clin Pathol 59: 685-691

Simpson ER, Mahendroo MS, Means GD, Kilgore MW, Hinshelwood MM, Graham-Lorence S, Amarneh B, Ito Y, Fisher CR, Michael MD, Mendelson CR, Bulun SE (1994) Aromatase cytochrome P450, the enzyme responsible for estrogen biosynthesis. Endocr Rev 15: $342-355$

Speake WJ, Dean RA, Kumar A, Morris TM, Scholefield JH, Watson SA (2005) Radiation induced MMP expression from rectal cancer is short lived but contributes to in vitro invasion. Eur J Surg Oncol 31: 869-874 
Thibodeau P, Kachadourian R, Lemay R, Bisson M, Day B, Paquette B (2002) In vitro pro- and antioxidant properties of estrogens. J Steroid Biochem Mol Biol 81: 227

Timoshenko AV, Xu GT, Chakrabarti S, Lala PK, Chakraborty C (2003) Role of prostaglandin E2 receptors in migration of murine and human breast cancer cells. Experiment Cell Res 289: 265-274

Wang JL, Sun Y, Wu S (2000) Gamma-irradiation induces matrix metalloproteinase II expression in a p53-dependent manner. Mol Carcinog 27: 252-258

White KE, Ding Q, Moore BB, Peters-Golden M, Ware LB, Matthay MA, Olman MA (2008) Prostaglandin E2 mediates IL-1beta-related fibroblast mitogenic effects in acute lung injury through differential utilization of prostanoid receptors. J Immunol 180: 637-646
Wild-Bode C, Weller M, Rimner A, Dichgans J, Wick W (2001) Sublethal irradiation promotes migration and invasiveness of glioma cells: implications for radiotherapy of human glioblastoma. Cancer Res 61: 2744-2750

Yang P, Felix E, Madden T, Fischer SM, Newman RA (2002) Quantitative high-performance liquid chromatography/electrospray ionization tandem mass spectrometric analysis of 2- and 3-series prostaglandins in cultured tumor cells. Analytical Biochem 308: 168-177

Yao M, Lam EC, Kelly CR, Zhou W, Wolfe MM (2004) Cyclooxygenase-2 selective inhibition with NS-398 suppresses proliferation and invasiveness and delays liver metastasis in colorectal cancer. Br J Cancer 90: 712 - 719

Zerkowski MP, Camp RL, Burtness BA, Rimm DL, Chung GG (2007) Quantitative analysis of breast cancer tissue microarrays shows high cox-2 expression is associated with poor outcome. Cancer Invest 25: 19-26 